\title{
Digitalisation potentials in the electricity ecosystem: lesson learnt from the comparison between Germany and Denmark
}

\author{
Thorsten Hack ${ }^{1 *}$, Zheng $\mathrm{Ma}^{2}$ and Bo Nørregaard Jørgensen ${ }^{1}$ \\ From 1st Energy Informatics.Academy Conference Asia \\ Beijing, China . 29-30 May 2021
}

\footnotetext{
* Correspondence: thah@mmmi. sdu.dk

${ }^{1}$ Centre for Energy Informatics, The Maersk Mc-Kinney Moller Institute, Odense, Denmark

Full list of author information is available at the end of the article
}

\begin{abstract}
Digitalisation potentials in the electricity sector are frequently discussed around the world, especially in Europe which has the largest interconnected continental electricity grid in the world. The analysis and comparison of electricity ecosystems between countries can help to enhance international understanding and cooperation. It can also enable businesses to expand. However, little literature has covered the cross-national comparisons of digitalisation potentials in the electricity sector. This paper uses the business ecosystem architecture development methodology to identify commonalities and differences between two electricity ecosystems: Germany and Denmark. The result shows that there are many similarities between the two countries, but the roles of market framework provider, market supervision, and metering point operator are performed by different actors. By comparing the value chain segments, the main differences between Denmark and Germany are the share of renewable energy generation, the organisation of the transmission system, smart meter installation \& operations, and the national electricity data hub. Based on the comparisons, six recommendations for the digitalisation of the electricity ecosystem are proposed: digitalisation for enabling more renewable energy resources for electricity generation, digitalisation in the electricity grids, digitalisation ib. the electricity markets, digitalisation on the demand side, especially the transport sector, and regulation-driven digitalisation of the electricity ecosystem.
\end{abstract}

Keywords: Digitalisation, Energy ecosystem, Electricity market, Demand side, Germany, Denmark (c) The Author(s). 2021 Open Access This article is licensed under a Creative Commons Attribution 4.0 International License, which permits use, sharing, adaptation, distribution and reproduction in any medium or format, as long as you give appropriate credit to the original author(s) and the source, provide a link to the Creative Commons licence, and indicate if changes were made. The images or other third party material in this article are included in the article's Creative Commons licence, unless indicated otherwise in a credit line to the material. If material is not included in the article's Creative Commons licence and your intended use is not permitted by statutory regulation or exceeds the permitted use, you will need to obtain permission directly from the copyright holder. To view a copy of this licence, visit http://creativecommons.org/licenses/by/4.0/. 


\section{Introduction}

Digitalisation potentials in the energy sector have been a rising topic all over the world, especially in Europe, the USA, and China (Qingnan Li 2016). Most of the discussion on digitalisation potentials focuses on the national level, especially with the national political agendas. However, from the business opportunities perspective, a cross-national comparison is essential for exporting energy technology in different countries.

So far only some literature has compared energy systems between countries. For instance, Ratinen and Lund (2012) compare how different countries, including Denmark and Germany, have reacted to the liberalisation of energy markets and how policies have influenced the growth of renewable energy production. In (Lipp 2007), different approaches to promote renewable energy production in several countries are compared, but this paper focuses on which policies and market mechanisms are the most effective to achieve this goal. In (Schultz et al. 2019), the political and regulatory impact on the adoption of demand response in Denmark and Austria is compared. Furthermore, in (Ma et al. 2015a), a comparison of smart grid transferability between Europe, the U.S., and China is conducted.

However, little literature has covered the cross-national comparisons of digitalisation potentials in energy. Therefore, this paper aims to fill this gap by conducting a crossnational comparison of the electricity systems between Germany and Denmark. These two countries are selected because both energy systems comply with the same EU regulations on electricity markets, and their electricity systems are interconnected at the market side and on the physical side via transmission lines. Since Germany and Denmark are neighbour countries, there has been lots of technology trading and collaboration between these two countries.

To investigate the digitalisation potentials in energy from the cross-national perspective, the understanding should cover the whole value chain including the energy system and the business aspects.

Complex systems can be modelled in various ways. One approach to modelling such systems is the Business ecosystem architecture development methodology which combines elements from system engineering and ecology (Ma 2019). The Business ecosystem architecture development method was introduced by (Ma et al. 2021). It is a hybrid modelling method that is different from standard system engineering and focuses not only on the roles and actors but also on their interactions.

In the business ecosystem modelling method, a business ecosystem has a clearly defined targeted business domain and a geographical or cultural boundary (Ma et al. 2019). While the German and Danish electricity markets have the same business domain, they form different ecosystems since they are in two different geographical boundaries. By only looking at supply chains, many stakeholders in the business ecosystem would not be considered, therefore the analysis of the business ecosystem brings additional insights (Ma et al. 2021).

By comparing the two business ecosystems of Denmark and Germany with the methodology proposed (Ma 2019), the similarities and differences are pointed out and may facilitate the identification of potentials and lessons between those two countries. This paper mainly focuses on digitalisation and communication between the stakeholders in the two electricity ecosystems. It also identifies potentials for enhancing cross-border 
collaborations regarding the physical energy flow, wholesale markets, and other aspects like research.

This paper firstly applies the ecosystem architecture method to compare the Danish and German electricity ecosystems regarding three aspects (actors, roles, and their interactions). Thereafter, the electricity value chain segments of electricity generation in Denmark and Germany are discussed and compared. This includes renewable energy resources, the transmission grid, electricity markets and imports \& exports. Afterwards, data sharing and the potentials of digitalisation on the demand side in these two electricity ecosystems are discussed. Finally, lessons Germany can learn from Denmark and vice versa are discussed.

\section{Methodology}

The proposed methodology for the ecosystem architecture design by (Ma et al. 2021) includes five stages (shown in Table 1). This paper mainly applies the first four stages for the investigation of similarities and differences between the German and Danish electricity ecosystem, since the main purpose of this paper is comparing, not designing an ecosystem architecture.

\section{Stage 1: boundary identification of a business ecosystem}

According to (Ma et al. 2021), the ecosystem boundary includes two dimensions: the targeted domain and the cultural/geographic boundary. In this paper, the geographical boundaries of the energy ecosystem match the country borders of Germany and Denmark. The targeted domain is the electricity system in the two countries. The primary supply chain comprises the process of generating electricity and transporting it to the consumers. Along with it, the markets where electricity is traded and regulations are also relevant.

\section{Stage 2: identification of actors and their roles in the business ecosystem}

In the business ecosystem architecture methodology, actors are types of stakeholders who directly participate in the ecosystem's value creation process (Ma et al. 2021). A role is defined as an actor's responsibility in the business ecosystem. At this stage, roles

Table 1 The five-stage business ecosystem architecture design approach (Ma et al. 2021)

\begin{tabular}{|c|c|}
\hline $\begin{array}{l}\text { Stage of the business ecosystem } \\
\text { architecture development }\end{array}$ & Purpose \\
\hline $\begin{array}{l}\text { Stage } 1 \text { - Boundary identification of a } \\
\text { business ecosystem }\end{array}$ & $\begin{array}{l}\text { - Define and describe the targeted business ecosystem boundary } \\
\text { with two dimensions (the targeted domain and the cultural/ } \\
\text { geographic boundary) }\end{array}$ \\
\hline $\begin{array}{l}\text { Stage } 2 \text { - Identification of actors and their } \\
\text { roles in the business ecosystem }\end{array}$ & - Identify actors and their roles \\
\hline $\begin{array}{l}\text { Stage } 3 \text { - Identification of actors' value } \\
\text { propositions }\end{array}$ & $\begin{array}{l}\text { - Identify value propositions for each role and identify the } \\
\text { potential interactions between roles }\end{array}$ \\
\hline $\begin{array}{l}\text { Stage } 4 \text { - Identification of interaction } \\
\text { between actors }\end{array}$ & - Identify the types and content of the interaction between roles \\
\hline $\begin{array}{l}\text { Stage } 5 \text { - Verification of business ecosystem } \\
\text { architecture design }\end{array}$ & $\begin{array}{l}\text { - Design minimum viable ecosystem and ecosystem roadmap } \\
\text { - Visualize the developed business ecosystem architecture } \\
\text { - Check completeness }\end{array}$ \\
\hline
\end{tabular}


are identified according to legal requirements for primary and/or secondary supply chains and markets, and actors are identified according to the roles assigned to them.

The actors and corresponding roles in the Danish and German electricity ecosystems are listed in Table 2. Although the two electricity ecosystems are similar, three roles are equivalent but performed by different actors: the role of the market framework provider, market supervision, and metering point operator.

\section{Stage 3: identification of actors' value propositions}

At this stage, the corresponding value proposition for each actor (directly related to their roles) is identified. Often, a value proposition also correlates with a business model. (Ma et al. 2021) also recommends that if an actor has several value propositions, they should be assigned to multiple roles.

The comparison of the Danish and German electricity ecosystems shows that grid operators and electricity producers are separated in Germany and Denmark because both countries follow the EU regulations on the liberalisation of energy markets. Electricity producers sell energy either directly to a supplier or at an energy exchange. Balance responsible parties buy and sell electricity on the spot market and try to match generation and demand in their balancing zone. They are liable to the balance coordinator for imbalances.

In both countries, the transport system operators (TSOs) are also national/regional balance responsible. Still, there is a difference in the responsibilities of the TSOs. The Danish transmission system operator Energinet is fully owned by the Danish state (Energinet 2020b). Therefore, tasks like setting a framework for the electricity market and ensuring fair prices are also assigned to Energinet. In Germany, there are four separate private TSOs for different zones. Therefore, tasks that go beyond the scope of operating and maintaining the grids are the responsibility of the Bundesnetzagentur

Table 2 Main actors and roles in the Danish and German electricity business ecosystem (Bundesnetzagentur 2016; Energinet 2020a)

\begin{tabular}{lll}
\hline Difference? & Actor & Role \\
\hline No & Electricity producer & Electricity producer \\
No & Transmission system operator (TSO) & Transmission system operator \\
& & Balance Coordinator \\
Yes & DK: Transmission system operator & Market framework provider \\
No & DE: Bundesnetzagentur (Federal grid agency) & \\
Yes & Distribution system operator (DSO) & Distribution system operator \\
Yes & DK: Danish Energy Regulatory Authority & Market supervision \\
No & DE: Bundesnetzagentur (Federal grid agency) & \\
No & DK: Distribution system operator & Metering point operator \\
No & DE: DSO or competitive meter operator & \\
No & Metering point administrator & Metered data collector \\
\hline The differences between the two countries are marked with "DK" for Denmark and "DE" for Germany
\end{tabular}


(federal grid agency). They also supervise the energy market. In Denmark, the Energy Regulatory Authority is responsible for the supervision.

On the consumption side, both in Denmark and Germany, consumers obtain their energy from an energy supplier. The supplier issues a single invoice to the consumer including all levies and taxes. The supplier is responsible for forwarding the taxes and levies to the government and the grid operators.

In Denmark, all metering devices are owned by the distribution system operator. They can delegate the installation, reading, and maintenance of the meters to a metering point administrator. In Germany, the metering point operator can be freely chosen by the consumers. Unless consumers choose to change it, the metering point owner is the DSO by default. Like in Denmark, the meter operator can choose to delegate work to a metering point administrator.

\section{Stage 4: identification of interaction between actors}

At stage 4, the types and content of the interaction between roles are identified. The interactions can be categorized into 5 types of flows as shown in Table 3 .

Since both Denmark and Germany are connected to the European continental grid and energy market, the monetary and tangible flows within the electricity value chain match each other. However, the data and information flows differ (shown in Table 4).

In Germany, the grid levies are set by the regulatory authority (Anreizregulierungsverordnung vom 29 2007). Consumers' information is private to the electricity supplier and is not sent to a central database like in Denmark. The same applies to metered data. In Denmark, where smart meters are installed at every grid connection, consumption data is sent to DataHub every hour (Energinet 2018). In Germany, SMARD (Bundesnetzagentur 2021a) is a data platform that visualises electricity data like consumption, generation, imports, and exports for Germany. In most German grid connections, however, the consumption data is manually recorded once a year. Exceptions apply for large consumers using more than 100,000 kWh a year. For these consumers, a smart meter is mandatory that can be accessed by the distribution system operators (Bundesministerium der Justiz und für Verbraucherschutz 2005). Therefore, electricity suppliers and balance responsible parties cannot read the consumption/production data from a central database. Instead, they get their information directly from the meter operators.

Table 3 Types of interactions in the business ecosystem (Ma et al. 2021)

\begin{tabular}{ll}
\hline Type of interaction & Description \\
\hline $\begin{array}{l}\text { Goods (Product \& } \\
\text { Service) }\end{array}$ & $\begin{array}{l}\text { The basic products of an economic system that consist of tangible consumable items } \\
\text { (products) and tasks performed by individuals (service). }\end{array}$ \\
Monetary value & $\begin{array}{l}\text { The amount of value an item or a service has if it was sold for cash to a buyer } \\
\text { Data }\end{array}$ \\
$\begin{array}{l}\text { Data that has been processed, organised, structured or presented to make it useful in a } \\
\text { given context }\end{array}$ \\
$\begin{array}{l}\text { Information } \\
\text { Intangible value }\end{array}$ & Something that exists but cannot be exactly described, or given an exact value. \\
\hline
\end{tabular}


Table 4 Data and information interactions in the Danish and German electricity ecosystem (Bundesnetzagentur 2016; Bundesnetzagentur 2021a; Energinet 2020a)

\begin{tabular}{|c|c|c|c|}
\hline Difference? & From Role / Object & Interaction Content & To Role / Object \\
\hline No & Electricity Producer & production bids & Balance Responsible Party \\
\hline No & Electricity Producer & production data & Metering Point \\
\hline No & $\begin{array}{l}\text { Balance Responsible } \\
\text { Party }\end{array}$ & production bids & Marketplace \\
\hline (No) & TSO & $\begin{array}{l}\text { imbalanced Production/consumption } \\
\text { data }\end{array}$ & $\begin{array}{l}\text { DK: DataHub } \\
\text { DE: SMARD }\end{array}$ \\
\hline Yes & TSO, DSO & subscription, fees and tariffs & $\begin{array}{l}\text { DK: DataHub } \\
\text { DE: - }\end{array}$ \\
\hline (No) & DSO & metered and settlement data & $\begin{array}{l}\text { DK: DataHub } \\
\text { DE: SMARD }\end{array}$ \\
\hline No & Electricity Supplier & consumption data & Balance Responsible Party \\
\hline Yes & Electricity Supplier & consumers' information update & $\begin{array}{l}\text { DK: DataHub } \\
\text { DE: - }\end{array}$ \\
\hline No & Electricity Consumer & consumption data & Metering Point \\
\hline Yes & Meter Point & production/consumption data & $\begin{array}{l}\text { DK: DataHub } \\
\text { DE: - / DSO (only for large } \\
\text { consumers) }\end{array}$ \\
\hline Yes & $\begin{array}{l}\text { DK: DataHub } \\
\text { DE: Meter Operator }\end{array}$ & consumption data & Electricity supplier \\
\hline Yes & $\begin{array}{l}\text { DK: DataHub } \\
\text { DE: Meter operator }\end{array}$ & production data & Balance responsible party \\
\hline
\end{tabular}

The differences between the two countries are marked with "DK" for Denmark and "DE" for Germany

\section{Comparison of electricity value chain between Germany and Denmark}

For identifying the differences between the Danish and German electricity ecosystems, the electricity value chain segments of electricity generation and renewable energy resources, transmission grid(s), electricity market and import/export in Denmark and Germany will be introduced and compared.

\section{Electricity generation and renewable energy resources}

In 2020, Denmark produced a total of 27,390 GWh of electricity or $4704 \mathrm{kWh}$ per capita (Eurostat 2020; International Energy Agency 2021). 82\% of the electricity was produced from renewable energy sources. This ranks Denmark in the top five among the OECD member countries. As shown in Fig. 1, by far, most electricity is produced from wind, accounting for almost $60 \%$ of the total electricity production in the country (International Energy Agency 2021). Denmark has both onshore and offshore wind power plants. The onshore sector produced $62 \%$ of the wind energy, while the offshore sector contributed 38\% in 2020 (Energinet 2021a).

Combustible renewables like biomass provide $18 \%$ of the locally produced energy followed by coal-fired power plants (10\%). Photovoltaics (4\%), power plants fired by natural gas (4\%), and other combustibles like waste (3\%) provide the remaining electricity. Oil-fired power plants and hydro-powered plants produce less than $1 \%$ of Denmark's electricity (International Energy Agency 2021).

Germany has a much larger land area and a higher population than Denmark, and therefore, also produces significantly more energy. In 2020, a total of 543,383 GWh were produced, which corresponds to $6534 \mathrm{kWh}$ per capita (Eurostat 2020; 


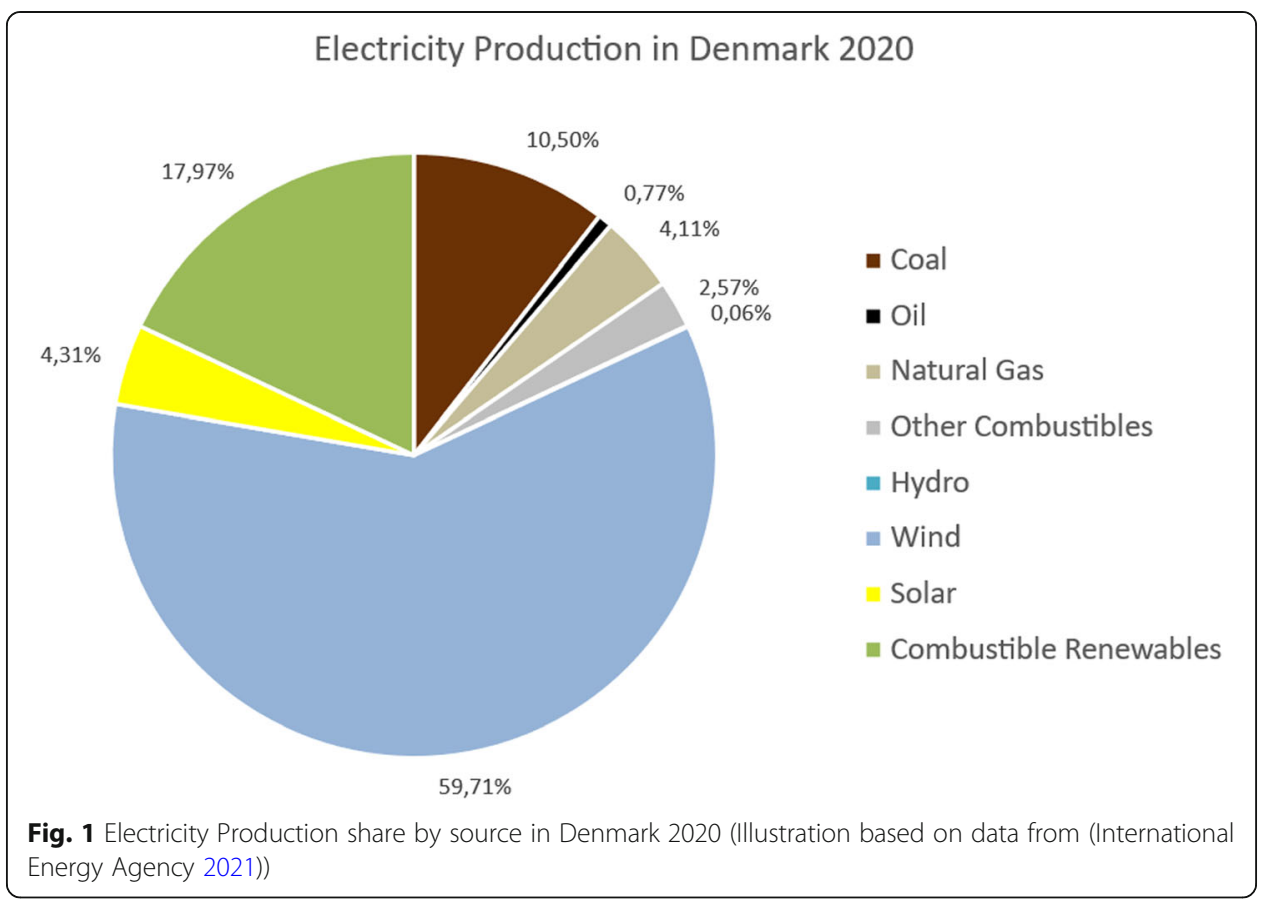

International Energy Agency 2021). In Germany, the energy sources for electricity are more diverse than in Denmark. The majority of electricity is still produced from nonrenewable sources. The share of renewables was at $47 \%$ in 2020 resulting in a middle rank among the OECD countries (International Energy Agency 2021).

Figure 2 shows the energy mix of Germany in 2020. Coal (lignite and hard coal combined) fired power plants are the single source of energy that provides the most energy

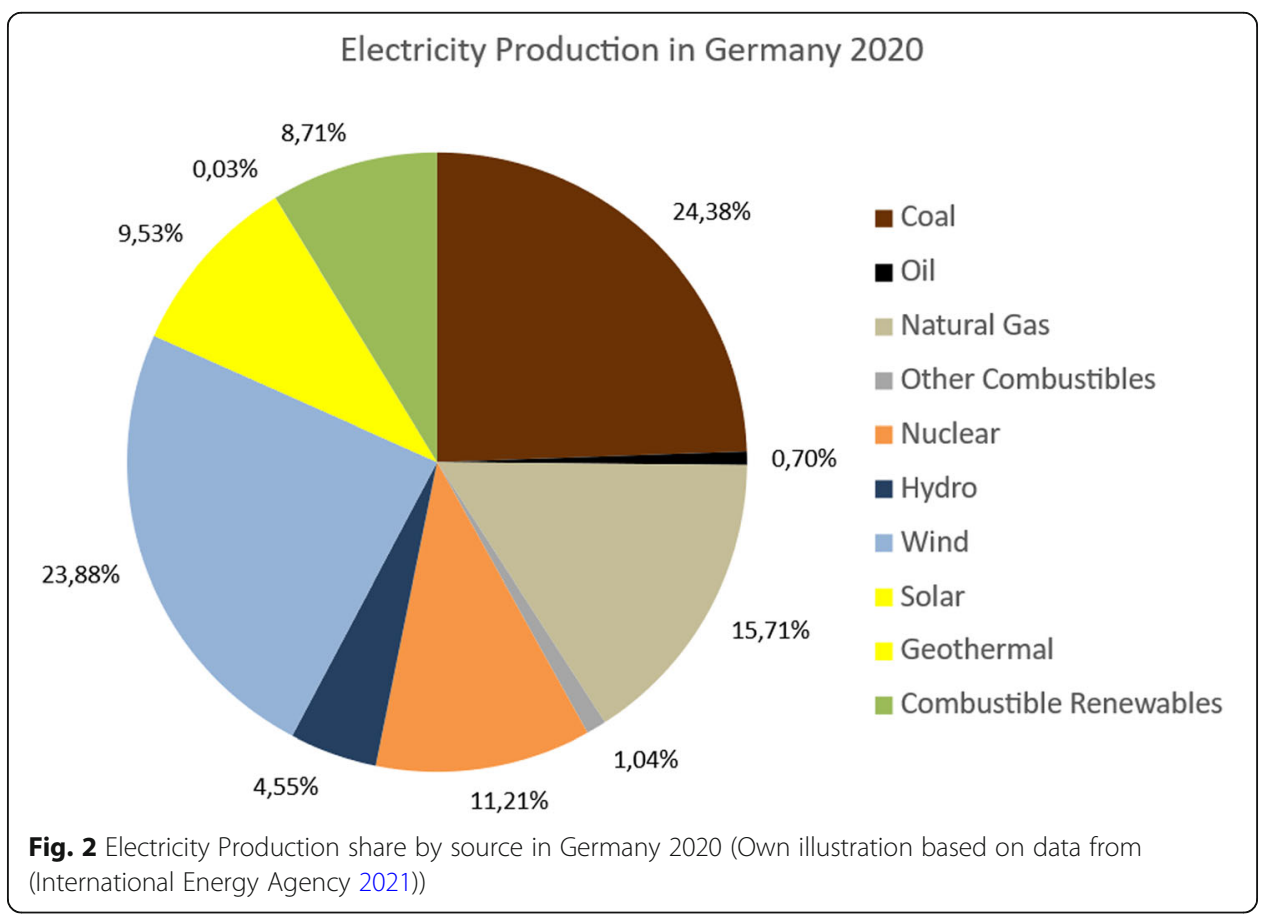


but still accounts for just $24 \%$ of the total energy production. Wind energy follows and provides also $24 \%$. Power plants fired by natural gas contribute $16 \%$ to electricity production. Nuclear power still produces $11 \%$, although Germany has decided to switch off all nuclear power plants before the end of 2022 (Bundesregierung 2011).

Apart from wind energy, Germany also uses the renewable energy sources photovoltaics (10\%), biomass (9\%), and hydroelectric power (5\%). Other energy sources like waste, oil and geothermal energy each account for $1 \%$ of the total energy production or less.

The comparison of the electricity production with different energy sources between Germany and Denmark during 2016-2020 shows a clear trend towards a higher share of renewable energy sources in both countries. Denmark has increased the share of renewable energy resources from $62 \%$ to $82 \%$ in 4 years, and Germany started at $31 \%$ in 2016 and reached $47 \%$ in 2020. In both countries, the energy from wind turbines contributes to the increased share while coal power plants produce significantly less energy in 2020 than in 2016 (from 28\% to 10\% in Denmark, and from $41 \%$ to $24 \%$ in Germany). A notable difference between the two countries can be seen in the use of natural gas for electricity production. Denmark used less gas for power generation in 2020 than in 2016 (from 7\% to 4\%), while Germany increased the share from 12\% to 16\% (International Energy Agency 2021).

\section{Transmission grid(s)}

The Danish transmission grid is operated by a single operator: Energinet.dk. A particularity of the Danish transmission grid is that despite being a rather small country the grid is split into two areas that are connected, but where the frequency is not synchronised. The West Danish grid consisting of mainland Denmark and Funen is synchronised with the European continental grid. The East Danish grid includes the islands of Zealand, Lolland, Falster, and Møn and is connected to the Nordic grid. The two transmission grid zones are connected across the Great Belt by a $600 \mathrm{MW}$ direct current (DC) connection. Besides, there are alternating current (AC) connections from East Denmark to Sweden and from West Denmark to Germany as well as DC connections to Germany, Sweden, and Norway (Sorknæs et al. 2013).

The entire German transmission grid is part of the European continental grid. Four transmission grid operators are each responsible for one part of the country. TransnetBW operates in the state of Baden-Württemberg, the southwest of Germany, $50 \mathrm{~Hz}$ serves East Germany and Hamburg. Amprion and Tennet divide the rest of West and South-East Germany. All transmission grid operators try to balance the supply and demand in their zones. They form a "grid control association "for this purpose. When supply and demand can't be balanced within a zone, balancing is attempted across all four zones before balancing energy is accessed (NeXT Kraftwerke 2019).

Via the synchronised continental grid, Germany is connected to all neighbouring countries via AC cables or lines. Also, there are DC interconnections to East Denmark, Sweden and Norway in the Nordic grid (ENTSO-E 2019).

\section{Electricity market, imports and exports}

There are two different kinds of power stock exchanges, the power derivatives market and the spot market. Energy can also be traded in bilateral agreements without any 
exchange being involved. This is called over-the-counter (OTC) trade (Bundesnetzagentur 2021b). There are notable differences between the German and the Nordic market (including Denmark, Sweden, Norway, Finland, and the Baltic states). In 2019, only about $25 \%$ of the trade volume (spot market and futures combined) are traded in exchanges in Germany, while exchanges account for $62 \%$ of the trade volume in the Nordic market (Market Observatory for Energy of the European Commission 2020).

Power derivatives, on the energy exchange also called Futures, do not involve the physical delivery of electricity. It is rather a financial instrument to secure the electricity price at a certain point in the future. Futures are used to minimise the risk of volatile spot market prices. Usually, the tradeable timespans range from days until years (Bundesnetzagentur 2021b). There are several exchanges where power derivates can be traded. For example, the European Energy Exchange (EEX) in Leipzig (Germany) offers power derivates for 20 European countries including Denmark and Germany (EEX 2021; Grave et al. 2015). The spot market is used to balance electricity supply and demand. Trading takes place either a day before delivery (day-ahead) or at the delivery day (intra-day) in intervals of $15 \mathrm{~min}$ or $1 \mathrm{~h}$. All offers to generate electricity are ordered by price (merit order). The offer that matches the demand determines the market-clearing price (Bundesnetzagentur 2021b).

In Europe, there are several spot markets. The main marketplace for Denmark and the Nordic countries is NordPool which is based in Oslo (Norway) (Energinet 2020a). EPEX Spot, based in Paris (France), is the main marketplace for Germany and several other central European countries (Grave et al. 2015).

As mentioned earlier, Denmark connects to both the Nordic grid and the continental European grid. These interconnections are frequently used for imports and exports of electricity. In 2020, a total of $12.9 \mathrm{GWh}$ were imported from the Nordic grid while only $1.9 \mathrm{GWh}$ were exported there. Compared to domestic production, the imports from Sweden and Norway are significant and account for 32\% of the electricity load in Denmark. The connection to the continental grid is mainly used for exporting energy. In 2020, $7 \mathrm{GWh}$ were exported to and $3.8 \mathrm{GWh}$ imported from Germany.

Germany trades a lot of electricity across borders since it has a lot of neighbour countries due to its location in the centre of Europe. In 2020, Germany has exported a total of $60 \mathrm{GWh}$ while having imported $41 \mathrm{GWh}$ of electricity. Therefore, Germany can be defined as a net exporter, since the accumulated electricity that is exported during a year exceeds the accumulated imports. Germany imports the most electricity from France (10 GWh net import) and Denmark ( $3 \mathrm{GWh}$ net import). The biggest export markets are Poland (11 GWh net export) and Austria (8 GWh net export) (Bundesnetzagentur 2021c).

\section{Data sharing and digitalisation potentials in German and Danish electricity ecosystems \\ Data sharing}

In the electricity system, data exchange between different actors is crucial to ensure a stable grid. For example, the grid providers need to know how much energy is produced and consumed in each region to determine how much balancing energy is needed. The EU regulation on the publication of data in electricity markets 
(Consolidated text: Commission Regulation (EU) No 543/2013 of 14 June 2013 on submission and publication of data in electricity markets and amending Annex I to Regulation (EC) No 714/2009 of the European Parliament and of the Council (Text with EEA relevance) Text with EEA relevance 2020) is binding for both Denmark and Germany. It stipulates what kind of data needs to be shared with whom. It also introduces a common European transparency platform, which is publicly available and shows generation, consumption, transmission, and outage data in real-time. Older data from the last 5 years is also available in an archive (ENTSO-E 2021). The transmission grid providers are responsible for sending the data to the European Network of Transmission System Operators for Electricity (ENTSO-E). The data includes but is not limited to load forecasts, generation forecasts, and information on planned and forced outages in both power plants and transmission lines.

In addition to the ENTSO-E transparency platform, both Germany and Denmark operate additional energy-related databases. In Germany, those platforms are operated by the Bundesnetzagentur, the federal agency, responsible for supervising and regulating the electricity market. In Germany, most of the data in SMARD is also sent to ENTSO$\mathrm{E}$, however, the real-time data is enhanced with detailed information regarding the power generation units. The Marktstammdatenregister ("market core data index") (Bundesnetzagentur 2021d) lists power generations units and other participants in the energy market and is also available for the public. All power generation units, including small rooftop photovoltaic systems, are required to register on the platform. The market participants who need to register include, for example, distribution grid providers, balance responsible parties, meter operators, and wholesalers.

In Denmark, the transmission grid provider, Energinet, operates a single database called DataHub (Energinet 2021b), that stores all electricity-system related data. This includes not only data about production, transmission, and market participants like in Germany, but also the metered data for all Danish consumers. All communication between market participants goes through the DataHub. Among other benefits, this simplifies the process of switching the electricity retailer for consumers and enables the retailers to issue a single bill that all costs including grid operation and taxes are included (Energinet 2018). Every electricity consumer has access to its own hourly consumption data in DataHub via a website (Energinet 2021c). Consumers can also grant third parties access to their hourly consumption data. Additionally, Danish researchers can access pseudonymised data via the Danish national statistics institute (Energinet 2018), and a wide range of raw data is publicly available as open data via the Energy Data Service that is also operated by Energinet (2021a). This includes but is not limited to consumption and production by municipality, wind and solar production forecasts, and load on transmission lines.

The main difference of data and information interactions between Denmark and Germany is the central data collection of all electricity fees and tariffs within DataHub in Denmark (shown in Table 4). This allows Denmark to create a central price comparison website (elpris.dk) (EL PRIS 2021) for both households and commercial consumers where all up-to-date tariffs are available. While in Germany electricity price comparison websites also exist, they are operated by independent businesses. These websites work by querying individual suppliers' websites. Therefore, they do not include all available tariffs and are also not always up to date. The comparison websites might 
also prefer suppliers that sell a higher provision. An independent and comprehensive system like in Denmark is therefore more favourable for consumers.

\section{Digitalisation potentials}

Digitalisation in the electricity ecosystem can support the path towards a fully renewable electricity system (Frankl 2019). Thereby digitalisation can happen along the whole value chain of the energy ecosystem, e.g., the generation side, the distribution side, and the demand side (Küfeoglu et al. 2019).

Table 4 (Data and information interactions in the Danish and German electricity ecosystem) shows that there are no notable differences between Denmark and Germany regarding data flows on the generation and distribution side. Also, a lot of literature and pilot studies have already been done in recent years in that area. For example, drones are used to inspect power plants and wind turbines to minimise maintenance costs and duration. Grid operators use weather forecasts to predict the production power of fluctuating renewable energy sources like wind and photovoltaics. Predictive maintenance both within power plants and grids helps to identify potential failures before they occur (Rhodes 2020).

Compared to the digitalisation potentials to the grids, the applications of digitalisation on the demand side are more dynamic. On the demand side, there are different types of consumers, e.g., households, commercial, industrial consumers, and transport (Ma et al. 2017a). Different consumers have different digitalisation potentials.

In 2019, the transport sector only accounted for $1,5 \%$ of domestic electricity consumption in Denmark. The rest of the electricity consumption is split almost equally between the three remaining sectors, each accounting for $33 \%$ of the electricity consumption (ENS (Danish Energy Agency) 2020). Germany is a more industry-focused country. In 2019, industry and agriculture used $46 \%$ of the total electricity consumption, trade and services accounted for 27\%, and households accounted for 25\%. Like in Denmark, the share of the transport sector is rather low (2\%) (Breitkopf 2020).

The data flow involving a household's metering point is one difference shown by the electricity ecosystem comparison. To benefit from digitalisation on the demand side, a smart meter needs to be installed at each grid connection point. Smart meters allow the electricity consumption to be measured and sent to the grid providers at least every hour.

In Germany, so far (March 2021), they are only mandatory for industrial consumers who use more than 100,000 kWh/year (Verordnung über den Zugang zu Elektrizitätsversorgungsnetzen 2005). For all other consumers, it is possible but optional to choose a meter operator that offers smart meters. Until 2019, only 0,74\% of all German households have installed smart meters (Statista 2021).

Denmark started the nationwide roll-out of smart meters in 2013. In 2014, half of the metering points already had smart meters installed (Energinet 2018). By law, all households need to have smart meters that connect to DataHub installed by the end of 2020 (Klima-, Energi- og Forsyningsministeriet 2019). In addition, all DSOs and electricity suppliers need to be able to handle hourly consumption data. As mentioned earlier, each consumer who has a smart meter installed can log in to a website (Energinet 2021c) to see their hourly consumption data. 
Two conditions can enhance the benefits for consumers with the installation of smart meters: the electricity prices can be adaptive to the current wholesale price; the loads can be potentially shifted to a time of the day when the electricity prices are lower.

In Germany, almost all domestic electricity prices are fixed prices per kilowatt-hour, independent from the current price at the energy exchange. As of 2021, there are only a few electricity tariffs where households can directly benefit from lower prices (for example (aWATTar Deutschland GmbH 2021; Tibber 2021)).

In Denmark, the situation is different. Since the households already have smart meters installed, they have the opportunity to get hourly electricity prices. Therefore, households in Denmark can choose between various flexible electricity prices. In March 2021, out of 150 electricity prices that danish households can choose from, 42 are both adaptive to the wholesale price and metered every hour (EL PRIS 2021).

The above observations regarding households are also valid for businesses in the trade and services sector. In Germany, the mandatory installation of smart meters for consumers using more than 10,000 kWh per year started in 2020 but was stopped again in March 2021 by a court (Oberverwaltungsgericht für das Land Nordrhein-Westfalen 2021). Therefore, few businesses have smart meters installed. In Denmark, all consumers including businesses have smart meters and access to flexible prices (EL PRIS 2021). Large energy consumers in the industry sector have direct access to the energy market and therefore can benefit from lower electricity prices.

In households, a lot of electricity is consumed by activities like cooking that are difficult to be shifted, or by appliances like fridges, that run constantly. Households have a few appliances that can be flexible, such as dishwashers, robot vacuum cleaners, washing machines, and dryers. However, Friis et al. (2016) study the Danish households and conclude that demand-side management is mostly seen as an inconvenience because although washing machines can run on their own, the clothes need to be put in a dryer or hung up after the machine has finished or they become smelly. They (Friis and Haunstrup 2016) also find that electric vehicle (EV) charging at night is quickly adopted as a routine when the overall electricity demand is generally lower. Paired with a device that automatically checks the current electricity prices, households with EVs can benefit from flexible electricity prices without losing convenience.

A similar situation arises when a household storage battery is available. They are usually installed in connection with a rooftop photovoltaic system to increase the use of self-produced electricity. It is also possible to store electricity from the grid in the batteries when electricity prices are cheap and the stored electricity can be used when electricity prices are high. Wu et al. (2017) developed an optimisation framework for home batteries, that does not require electricity from the grid in the morning and evening peak times. Instead, the battery is discharged at peak times and charged with selfproduced photovoltaic energy in the afternoon and from the grid at night.

Instead of using a battery to store the electricity, a similar load shifting potential can be achieved by storing the electricity as heat, for example in connection with an electrical hot water boiler or a heat pump (Patteeuw et al. 2016). Given the hot water tank is well isolated, the boiler or heat pump can heat water when electricity prices are low so it can be used for showering or space heating during peak times.

For the trade and services sector, the load shifting potential is rather low. A retail store consumes energy while it is opened. However, analogous to households, a 
photovoltaic system, a battery or heat storage can contribute to load flexibility (Ma et al. 2017a). Also, there are examples where a supermarket provides flexibility to the grid by lowering the freezing temperatures when there's an electricity surplus in the grid (Mlecnik et al. 2020).

Large industrial consumers not only use the most energy but also have the largest financial incentive to shift loads into hours where the electricity price is low since they buy their electricity directly at the electricity market. Depending on the business, storage systems like hot and cold water tanks, compressed air, or batteries can be used. Besides, an industrial process can be interrupted, changed or adjusted (Weeber et al. 2017).

Digitalisation in agriculture is a frequently discussed topic in academics. Digital technologies like sensor-based real-time monitoring and big data analysis are expected to provoke significant changes in the agricultural systems or even a disruption (Fielke et al. 2020). This also enables demand response in the agricultural sector. For example, Kocaman et al. (2020) found that pumping water for irrigation offers a high amount of flexibility.

\section{Discussion}

The comparison of the electricity systems and the electricity markets in Denmark and Germany shows that there are many similarities between Germany and Denmark. Both countries need to comply with EU standards and regulations that ensure a homogenous electricity system and trading between member states is possible. The roles in the electricity ecosystem are mostly identical between the two countries. However, some of the roles are performed by different actors. In Denmark, the TSO, Energinet, also supervises the market and operates the DataHub, a central energy database. In Germany, the Bundesnetzagentur (federal grid agency) is responsible for operating the energy-related databases and supervising the market.

The sources of electricity generation are more diverse in Germany compared to Denmark as shown by the comparison of electricity production and renewable energy resources. Non-renewable sources still produce the majority of the electricity in Germany (53\%), among them coal, natural gas, and nuclear power. Due to geographical circumstances, Germany has a higher potential to use hydro and solar power. Denmark produces most of its electricity from wind and biomass. Only $18 \%$ of the electricity is still produced from non-renewable sources like coal and natural gas.

Another significant difference between the two countries is the rollout of smart meters. In Denmark, smart meters are already installed for all consumers. In Germany a law for introducing smart meters in households and businesses was adopted in 2016 (Bundesministerium für Justiz und Verbraucherschutz 2016), the rollout still hasn't begun though. It is possible to voluntarily choose a metering operator that offers smart meters but at one's own expense.

In Denmark, there is a central data hub collecting all electricity fees and tariffs. The Danish TSO, Energinet, operates the DataHub that all market participants use to exchange their data using common protocols. This DataHub also allows third parties to access consumer data which creates new business models. In Germany, there is no such central DataHub, instead, the market participants exchange data directly with each other.

The comparison between Denmark and Germany also shows how regulations influence the focuses and progress in the digitalisation of the electricity ecosystems. For 
instance, there are more digitalisation potentials and there will be more related activities in the industrial sector in Germany due to intensive energy use and smart meter installation. Meanwhile, there are more digitalisation potentials and there will be more related activities in the residential sector in Denmark, also due to smart meter installation, DataHub, and also data sharing via living labs. Meanwhile, stakeholders' roles are also decided by the regulations, and therefore, their corresponded business models are influenced (Ma et al.). For instance, in Denmark, distribution system operators own, maintain, and collect meter data from the meter points. Comparatively, either distribution system operators or third parties can operate the meter points.

\section{Conclusion}

Digitalisation in the energy sector is not a regional standalone. All electricity systems in Europe are interconnected, and the discussion of digitalisation potentials should include the analysis of the electricity systems among countries.

This paper compares different aspects of the electricity systems in Denmark and Germany using the ecosystem architecture design method. The majority of the elements in the electricity ecosystem are similar between Germany and Denmark, and some detailed implementations in the electricity system between Denmark and Germany are different (shown in Table 5).

Digitalisation potentials in the electricity sector exist on the generation side, the distribution side, and the demand side (Ma et al. 2017b). Based on the comparisons between Denmark and Germany, the following recommendation for the digitalisation potentials in the electricity ecosystems are proposed in this paper:

- Digitalisation for enabling more renewable energy resources for electricity generation

The EU aims to reach climate neutrality by 2050 . However, to ensure the security of supply with renewable energy resources, large implantation of the digitalisation solutions at the generation side is needed. However, for large countries like Germany, it might take a longer time.

- Digitalisation in the electricity grids (transmission and distribution grids) Data and information sharing is essential for communication among stakeholders in the electricity ecosystem, especially for grid stabilisation, e.g. avoiding grid overloads with distributed energy resources (Ma et al. 2015b). Therefore, digitalisation solutions, such as DataHub in Denmark can serve this purpose. However, it requires regulatory support

- Digitalisation in the electricity markets To promote more electricity generated by renewable energy sources, digitalisation solutions in the markets are necessary. These solutions allow more efficient electricity bidding by accurate prediction, enable direct market participation for small electricity consumers and producers, and simplify cross-border electricity trading by data sharing (Zheng et al. 2016).

- Digitalisation on the demand side

On the demand side, the industry and agriculture sectors have the biggest potential to shift loads according to price signals from the electricity market (Ma et al. 2018). However, households and commerces can also benefit from flexible electricity 
Table 5 Summary of differences in electricity ecosystem between Denmark and Germany

\begin{tabular}{|c|c|c|}
\hline $\begin{array}{l}\text { Differences in } \\
\text { electricity } \\
\text { ecosystem }\end{array}$ & Denmark & Germany \\
\hline $\begin{array}{l}\text { Electricity } \\
\text { Production }\end{array}$ & $\begin{array}{l}82 \% \text { of the electricity was produced from } \\
\text { renewable energy sources }\end{array}$ & $\begin{array}{l}47 \% \text { of the electricity was produced from } \\
\text { renewable energy sources }\end{array}$ \\
\hline $\begin{array}{l}\text { Transmission } \\
\text { Grid }\end{array}$ & $\begin{array}{l}\text { Operated by a single operator Energinet.dk } \\
\text { West Danish grid consisting of mainland } \\
\text { Denmark and Funen is synchronised with the } \\
\text { European continental grid. }\end{array}$ & $\begin{array}{l}\text { Four transmission grid operators are each } \\
\text { responsible for one part of the country. } \\
\text { Is part of the European continental grid. }\end{array}$ \\
\hline $\begin{array}{l}\text { Electricity } \\
\text { imports and } \\
\text { exports }\end{array}$ & Net importer & Net exporter \\
\hline $\begin{array}{l}\text { Electricity } \\
\text { Market }\end{array}$ & NordPool spot market & EPEX Spot market \\
\hline $\begin{array}{l}\text { Role of Market } \\
\text { framework } \\
\text { provider }\end{array}$ & $\begin{array}{l}\text { Performed by the transmission system } \\
\text { operator }\end{array}$ & $\begin{array}{l}\text { Performed by Bundesnetzagentur (Federal } \\
\text { grid agency) }\end{array}$ \\
\hline $\begin{array}{l}\text { Role of Market } \\
\text { supervision }\end{array}$ & $\begin{array}{l}\text { Performed by danish energy regulatory } \\
\text { authority }\end{array}$ & $\begin{array}{l}\text { Performed by Bundesnetzagentur (Federal } \\
\text { grid agency) }\end{array}$ \\
\hline $\begin{array}{l}\text { Role of } \\
\text { Metering point } \\
\text { operator }\end{array}$ & Performed by the distribution system operator & $\begin{array}{l}\text { Performed by DSO or competitive meter } \\
\text { operator }\end{array}$ \\
\hline Smart meters & $\begin{array}{l}\text { Nationwide roll-out of smart meters since } \\
2013 ; \\
\text { All households need to have smart meters } \\
\text { that connect to DataHub installed by the end } \\
\text { of } 2020\end{array}$ & $\begin{array}{l}\text { Only mandatory for industrial consumers } \\
\text { who use more than } 100,000 \mathrm{kWh} / \text { year }\end{array}$ \\
\hline $\begin{array}{l}\text { Data and } \\
\text { information } \\
\text { sharing }\end{array}$ & $\begin{array}{l}\text { DataHub, stores all electricity-system related } \\
\text { data. This includes data about production, } \\
\text { transmission, and market participants, the } \\
\text { metered data for all Danish consumers. } \\
\text { All communication between market } \\
\text { participants goes through the DataHub }\end{array}$ & $\begin{array}{l}\text { SMARD, a data platform that visualises } \\
\text { electricity data } \\
\text { Marktstammdatenregister (market core data } \\
\text { index) lists power generations units and } \\
\text { other participants in the energy market }\end{array}$ \\
\hline Electricity prices & $\begin{array}{l}\text { Households in Denmark can choose between } \\
\text { various flexible electricity prices }\end{array}$ & $\begin{array}{l}\text { Almost all domestic electricity prices are } \\
\text { fixed prices }\end{array}$ \\
\hline
\end{tabular}

prices if they have flexible appliances, distributed energy resources like photovoltaics or storage systems (Ma et al. 2017c). Smart meters are the precondition for flexible electricity prices. Promoting the rollout of smart meters would provide general access to flexible electricity prices and detailed electricity consumption information. This might motivate more households to invest in distributed renewable energy resources or flexible appliances (Ma et al. 2016b).

- Digitalisation in the transport sector

Compared to the industry, agriculture, commerce, and households, the share of the transport sector in the domestic electricity consumption is rather low $(1,5 \%$ in Denmark and 2\% in Germany). Due to the increasing number of electric vehicles (EV), more EV charging solutions (both EV home charging and charging stations) appear (Fatras et al. 2020). It influences not only EV owners, EV charging solution providers, distribution system operators, and also electricity suppliers. Therefore, harmonised digitalisation solutions are needed.

- Regulation-driven digitalisation of electricity ecosystem Technologies for digitalising the electricity ecosystem have been discussed in the literature for decades. However, regulations influence the digitalisation focuses and the progress of the electricity ecosystems, as well as the stakeholders' roles and 
their business models (Mlecnik et al. 2019). Therefore, regulations are the main drivers for the digitalisation potentials and activities that can happen in a country.

This paper mainly focuses on the electricity ecosystems of Denmark and Germany with a broad overview and comparison. It excluded the gas market and does not go into the mobility and heating sectors, which also use a lot of energy. Future works may focus on a specific sector and its digitalisation potentials. Meanwhile, available digitalisation solutions and their implementation progress and factors that influence the digitalisation of the electricity ecosystem are not discussed in this paper that might be necessary to be investigated in the future. Furthermore, comparisons with countries outside the EU (European Union) are recommended that might bring more dynamic aspects due to different electricity regulations and market structures.

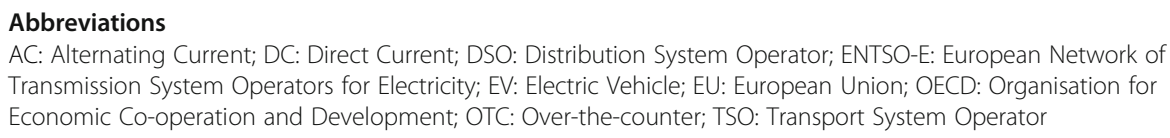

\section{Acknowledgements}

Thank you to Ben Lenk-Ostendorf and Annkatrin Linde for proofreading the manuscript.

\section{About this supplement}

This article has been published as part of Energy Informatics Volume 4, Supplement 2 2021: Proceedings of the Energy Informatics.Academy Conference Asia 2021. The full contents of the supplement are available at https:// energyinformatics.springeropen.com/articles/supplements/volume-4-supplement-2.

\section{Authors' contributions}

$T H, Z M$ and BNJ initiate the paper idea; TH conducts the draft of the paper, and ZM and BNJ contribute to the final manuscript. All authors read and approved the final manuscript.

\section{Funding}

Not applicable.

\section{Availability of data and materials}

Not applicable.

\section{Declarations}

Ethics approval and consent to participate

Not applicable.

\section{Consent for publication \\ Not applicable.}

\section{Competing interests}

Not applicable.

\section{Author details}

${ }^{1}$ Centre for Energy Informatics, The Maersk Mc-Kinney Moller Institute, Odense, Denmark. ${ }^{2}$ Centre for Health Informatics and Technology, The Maersk Mc-Kinney Moller Institute, Odense, Denmark.

Published: 24 September 2021

\section{References}

Anreizregulierungsverordnung vom 29. Oktober 2007 (BGBI. I S. 2529), die zuletzt durch Artikel 3 der Verordnung vom 23. Dezember 2019 (BGBl. I S. 2935) geändert worden ist. 2007

aWATTar Deutschland GmbH. Tarif Hourly 2021. Available from: https://www.awattar.de/tariffs/hourly. Accessed 21 Mar 2021 Klima-, Energi- og Forsyningsministeriet (2019), Bekendtgørelse om fjernaflæste elmålere og måling af elektricitet i slutforbruget. Available from https://www.retsinformation.dk/eli/ta/2019/75. Accessed 18 Mar 2021

A Breitkopf. Verteilung des Stromverbrauchs in Deutschland nach Verbrauchergruppen im Jahr 2019: Statista; 2020. Available from: https://de.statista.com/statistik/daten/studie/236757/umfrage/stromverbrauch-nach-sektoren-in-deutschland/ \#professional. Accessed 18 Mar 2021

Bundesministerium der Justiz und für Verbraucherschutz (2005), Verordnung über den Zugang zu Elektrizitätsversorgungsnetzen. Available from https://www.gesetze-im-internet.de/stromnzv/BJNR224300005.html. Accessed 18 Mar 2021 
Bundesministerium für Justiz und Verbraucherschutz. Messstellenbetriebsgesetz vom 29. August 2016 (BGBI. I S. 2034), das zuletzt durch Artikel 5 des Gesetzes vom 21. Dezember 2020 (BGBI. I S. 3138) geändert worden ist. 29. August 2016

Bundesnetzagentur. Definitionen der Marktakteure und deren Daten. 2016

Bundesnetzagentur. SMARD.de Benutzerhandbuch. 2021a

Bundesnetzagentur. Großhandelspreise 2021b. Available from: https://www.smard.de/page/home/wiki-article/446/562. Accessed 24 March 2021

Bundesnetzagentur. Smard - Marktstromdaten 2021c. Available from: https://www.smard.de/page/home/marktdaten/78. Accessed 26 Mar 2021

Bundesnetzagentur. Webhilfe des Marktstammdatenregisters 2021d. Available from: https://www.marktstammdatenregister. de/MaStRHilfe/subpages/zieleKonzepte.html. Accessed 23 Mar 2021

Bundesregierung. Bundesregierung beschließt Ausstieg aus der Kernkraft bis 2022 2011. Available from: https:/www.bundesregierung.de/ breg-de/suche/bundesregierung-beschliesst-ausstieg-aus-der-kernkraft-bis-2022-457246. Accessed 17 Mar 2021

Consolidated text: Commission Regulation (EU) No 543/2013 of 14 June 2013 on submission and publication of data in electricity markets and amending Annex I to Regulation (EC) No 714/2009 of the European Parliament and of the Council (Text with EEA relevance) Text with EEA relevance, (2020)

EEX. Power Derivates Market 2021. Available from: https://www.eex.com/en/markets/power-derivatives-market. Accessed 24 Mar 2021

EL PRIS. EL PRIS.dk 2021. Available from: https://elpris.dk/\#/results. Accessed 23 Mar 2021

Energinet. The Danish Electricity Retail Market. 2018

Energinet. Roles \& responsibilities 2020a. Available from: https://en.energinet.dk/Electricity/New-player/Roles-andresponsibilities. Accessed 24 Mar 2021

Energinet. Organisation - Energinet 2020b. Available from: https://en.energinet.dk/About-us/Organisation. Accessed 24 Mar 2021

Energinet. Electricity Balance Non-Validated: Energi Data Service; 2021a. Available from: https://www.energidataservice.dk/tsoelectricity/electricitybalancenonv. Accessed 25 Mar 2021

Energinet. What is the purpose of DataHub? 2021b. Available from: https://en.energinet.dk/Electricity/DataHub\#Documents. Accessed 23 Mar 2021

Energinet. Direkte adgang til dit eloverblik 2021c. Available from: https://eloverblik.dk/. Accessed 23 Mar 2021

ENS (Danish Energy Agency). Annual and monthly statistics 2020. Available from: https://ens.dk/en/our-services/statistics-datakey-figures-and-energy-maps/annual-and-monthly-statistics. Accessed 18 Mar 2021

ENTSO-E. ENTSO-E Transmission System Map 2019. Available from: https://www.entsoe.eu/data/map/. Accessed 17 Mar 2021

ENTSO-E. Transparency Platform 2021. Available from: https://transparency.entsoe.eu/. Accessed 23 Ma 2021

Eurostat. Population on 1 January 2021 updated 01.01.2020. Available from: https://ec.europa.eu/eurostat/web/populationdemography-migration-projections/background. Accessed 26 Mar 2021

Fatras N, Ma Z, Jørgensen BN (2020) Suitability assessment of electricity market mechanisms for electric vehicle grid integration. In: 2020 IEEE International Conference on Power Systems Technology (POWERCON); 2020 14-16 Sept

Fielke S, Taylor B, Jakku E (2020) Digitalisation of agricultural knowledge and advice networks: a state-of-the-art review. Agric Syst 180:102763. https://doi.org/10.1016/j.agsy.2019.102763

Frankl P (2019) Energy system debate: what lies ahead for the future [in my view]. IEEE Power Energy Mag 17(2):100-198. https://doi.org/10.1109/MPE.2018.2884118

Friis F, Haunstrup CT (2016) The challenge of time shifting energy demand practices: insights from Denmark. Energy Res Soc Sci 19:124-133. https://doi.org/10.1016/j.erss.2016.05.017

Grave K, von Blücher F, Breitschopf B, Pudlik M (2015) Strommärkte im internationalen Vergleich. Bundesministerium für Umwelt, Naturschutz und Reaktorsicherheit, June

International Energy Agency. Monthly electricity statistics Paris: IEA; 2021. Available from: https://www.iea.org/reports/ monthly-electricity-statistics. Accessed 16 Mar 2021

Kocaman AS, Ozyoruk E, Taneja S, Modi V (2020) A stochastic framework to evaluate the impact of agricultural load flexibility on the sizing of renewable energy systems. Renew Energy 152:1067-1078. https://doi.org/10.1016/j.renene.2020.01.129

Küfeoglu S, Liu G, Anaya K, Pollitt M (2019) Digitalisation and new business models in energy sector

Lipp J (2007) Lessons for effective renewable electricity policy from Denmark, Germany and the United Kingdom. Energy Policy 35(11):5481-5495. https://doi.org/10.1016/j.enpol.2007.05.015

Ma Z (2019) Business ecosystem modeling- the hybrid of system modeling and ecological modeling: an application of the smart grid. Energy Inf 2(1):35. https://doi.org/10.1186/s42162-019-0100-4

Ma Z, Asmussen A, Jørgensen B (2018) Industrial consumers' smart grid adoption: influential factors and participation phases. Energies. 11(1):182. https://doi.org/10.3390/en11010182

Ma Z, Badi A, Jørgensen BN (2016C) Market opportunities and barriers for smart buildings. In: 2016 IEEE green energy and systems conference (IGSEC); 2016 6-7 Nov, Long Beach,USA, 6-7 Nov. 2016 IEEE, pp. 1-6. https://doi.org/10.1109//GESC.2 016.7790078

Ma Z, Lundgaard M, Jørgensen BN (2016a) "Triple-layer smart grid business model: A comparison between sub-Saharan Africa and Denmark," in 2016 IEEE Innovative Smart Grid Technologies - Asia (ISGT-Asia), Melbourne, Australia. pp. 347352. IEEE, https://doi.org/10.1109/ISGT-Asia.2016.7796410

Ma Z, Billanes J, Jørgensen B (2017b) Aggregation potentials for buildings_business models of demand response and virtual power plants. Energies. 10(10):1646

Ma Z, Billanes JD, Jørgensen BN (2017c) A Business Ecosystem Driven Market Analysis: The Bright Green Building Market Potential. In: The 1st Annual International Conference of the IEEE Technology and Engineering Management Society. IEEE, Santa Clara

Ma Z, Billanes JD, Kjærgaard MB, Jørgensen BN, editors. Energy flexibility in retail buildings: From a business ecosystem perspective. 2017 14th International Conference on the European Energy Market (EEM); 2017 6-9 June 2017a

Ma Z, Broe M, Fischer A, Sørensen TB, Frederiksen MV, Jøergensen BN (2019) Ecosystem thinking: creating microgrid solutions for reliable power supply in India's power system the IEEE global power, energy and communication conference 2019 (IEEE GPECOM 2019); June 12-15. IEEE, Cappadocia 
Ma Z, Christensen K, Jørgensen BN (2021) Business ecosystem architecture development: a case study of electric vehicle home charging. Energy Informatics. 4(1). https://doi.org/10.1186/s42162-021-00142-y

Ma Z, Prljaca Z, Jørgensen BN (2015a) Global Smart Grid Transferability: Insights from Europe, the U.S., and China. J Energy Power Eng 9:1078-1092

Ma Z, Sommer S, Jørgensen BN (2015b) Smart grid in China: The key stakeholders, policies, regulations and challenges, in WIT Transactions on the Built Environment, Advanced Civil, Urban and Environmental Engineering, J. Yeh, Ed. vol. 157. WIT Press, https://doi.org/10.2495/CUEE140861

Market Observatory for Energy of the European Commission. Quarterly report on European electricity markets. 2020

Mlecnik E, Parker J, Ma Z, Corchero C, Knotzer A, Pernetti R (2019) "Policy challenges for the development of energy flexibility services," Energy Policy, p. 111147. https://doi.org/10.1016/j.enpol.2019.111147

Mlecnik E, Parker J, Ma Z, Corchero C, Knotzer A, Pernetti R (2020) Policy challenges for the development of energy flexibility services. Energy Policy 137:111147. https://doi.org/10.1016/j.enpol.2019.111147

NeXT Kraftwerke. Was ist eine Regelzone? 2019. Available from: https://www.next-kraftwerke.de/wissen/regelzone. Accessed 17 Mar 2021

Oberverwaltungsgericht für das Land Nordrhein-Westfalen. Oberverwaltungsgericht stoppt vorläufig Einbauverpflichtung für intelligente Messsysteme (Stromzähler) 2021. Available from: https://www.ovg.nrw.de/behoerde/presse/ pressemitteilungen/18_210305/index.php. Accessed 26 Mar 2021

Patteeuw D, Henze GP, Helsen L (2016) Comparison of load shifting incentives for low-energy buildings with heat pumps to attain grid flexibility benefits. Appl Energy 167:80-92. https://doi.org/10.1016/j.apenergy.2016.01.036

Qingnan Li ZM (2016) Bo Nørregaard Jørgensen editor discussion on China's power sector reforms and where to next? The 13th European energy market conference. EEM 2016, Porto

Ratinen M, Lund P (2012) Analysing changes in electricity industries against actors and technologies: utility to business transformations in Denmark, Germany, Finland and Spain. J Technol Manag Innov 7(2):87-100. https://doi.org/10.4067/ S0718-27242012000200008

Rhodes A (2020) Digitalisation of energy

Schultz MJ, Friis HTA, Ma Z, Jørgensen BN, editors. A cross-national comparative study of the political and regulatory impact on the adoption of demand response in Denmark and Austria. ECEEE 2019 Summer Study on energy efficiency; 2019 0308 June 2019; Presqu'île de Giens, Hyères, France: European Council for an Energy Efficient Economy (ECEEE)

Sorknæs P, Mæng H, Weiss T, Andersen AN (2013) Overview of the Danish power system and RES integration

Statista. Verteilung der Stromzählerarten in deutschen Haushalten im Jahr 2019 2021. Available from: https:/de.statista.com/ statistik/daten/studie/298727/umfrage/verteilung-der-zaehlertechnik-in-deutschen-haushalten/. Accessed 26 Mar 2021

Tibber. Tibber | Dein Stromvertrag für das digitale Zeitalter 2021. Available from: https://tibber.com/de. Accessed 23 Mar 2021

Weeber M, Lehmann C, Böhner J, Steinhilper R (2017) Augmenting energy flexibility in the factory environment. Procedia CIRP 61:434-439. https://doi.org/10.1016/j.procir.2016.12.004

Wu X, Hu X, Teng Y, Qian S, Cheng R (2017) Optimal integration of a hybrid solar-battery power source into smart home nanogrid with plug-in electric vehicle. J Power Sources 363:277-283. https://doi.org/10.1016/j.jpowsour.2017.07.086

Zheng M, Prljaca Z, Jørgensen BN (2016) The international electricity market infrastructure-insight from the nordic electricity market. In: 2016 13th International Conference on the European Energy Market (EEM); 2016 6-9 June

\section{Publisher's Note}

Springer Nature remains neutral with regard to jurisdictional claims in published maps and institutional affiliations.

\section{Submit your manuscript to a SpringerOpen ${ }^{\circ}$ journal and benefit from:}

- Convenient online submission

- Rigorous peer review

- Open access: articles freely available online

- High visibility within the field

- Retaining the copyright to your article

Submit your next manuscript at $\boldsymbol{\sim}$ springeropen.com 